\title{
Montagem e apropriação no cinema de John Akomfrah
}

\author{
Montage and appropriation in the cinema of John Akomfrah
}

\section{Rodrigo Sombra}

É professor adjunto do curso de Audiovisual da Universidade Federal do Mato Grosso do Sul (UFMS). Doutor em Comunicação pela UFRJ, com doutorado sanduíche na New York University (bolsa CAPES). Mestre em Estudos de Cinema pela San Francisco State University (SFSU).

\section{RESUMO:}

0 artigo investiga a dinâmica de reemprego de materiais de arquivo no cinema de John Akomfrah. Argumento que em sua obra a montagem assume uma veia ensaística, encarnando um "cinema de ideias", ao mesmo tempo em que admite uma relativa autonomia dos fragmentos apropriados. Este segundo movimento se sustenta no reconhecimento, por parte do artista, de que a raiz indicial da imagem fílmica seria em parte irredutível aos encadeamentos do discurso. Esta proposição se apoia numa análise do filme As Canções de Handsworth (1986), no qual Akomfrah põe em diálogo os levantes raciais então em curso na Inglaterra thatcherista e as aspirações de antilhanos emigrados na Grã-Bretanha do pósguerra.

PALAVRAS-CHAVE: cinema negro; filme-ensaio; arquivo; diáspora africana

\section{ABSTRACT:}

This paper examines the dynamics of the reuse of archival materials in John Akomfrah's cinema. I argue that editing takes on an essayistic vein in his work, embodying a "cinema of ideas", while admitting a relative autonomy of the appropriated images. This second movement is based on the artist's recognition that the indexical root of the filmic image would be in part irreducible to the chains of discourse. This proposition is supported by an analysis of the film Handsworth Songs (1986), in which Akomfrah brings into dialogue the racial uprisings then underway in Thatcherite England and the aspirations of West Indian emigrants in post-war Britain.

KEYWORDS: Black cinema; essay film; archive; African diaspora

Dossiê Apropriações e ressignificações na arte e no pensamento - https://revistaecopos.eco.ufrj.br/ 


\section{RESUMEN:}

El artículo investiga la dinámica de la reutilización de materiales de archivo en el cine de John Akomfrah. Sostengo que en su obra el montaje adquiere una vena ensayística, encarnando un "cine de ideas", al tiempo que admite una relativa autonomía de los fragmentos apropiados. Este segundo movimiento se basa en el reconocimiento del artista de que la indicialidad de la imagen fílmica sería en parte irreductible a las cadenas del discurso. Esta propuesta se apoya en un análisis de la película Las Canciones de Handsworth (1986), en la que Akomfrah pone en diálogo los levantamientos raciales que se estaban produciendo en la Inglaterra thatcheriana y las aspiraciones de los emigrantes antillanos en la Gran Bretaña de la posguerra.

PALABRAS CLAVE: cine negro; film-ensayo; archivo; diáspora africana

A poética do cineasta britânico John Akomfrah encerra, antes de qualquer coisa, um jogo de disfarces. Falar em Akomfrah é adentrar o universo de um realizador menos inclinado à encenação ou a apontar a câmera às aparências do mundo, do que a identificar nas criações dos outros - filmes, fotografias, pinturas, textos - o seu principal recurso, a matéria-prima fundante de seu cinema. Uma poética de disfarces assentada num meticuloso trabalho de pesquisa, acúmulo e montagem de materiais preexistentes. Seja em videoinstalações inspiradas em obras icônicas, a exemplo de Peripeteia (2012), cuja montagem retalha fragmentos d' “O Jardins das Delícias Terrenas”, de Bosch, ou das vozes literárias de Beckett e Milton incorporadas em Mnemosyne (2010), seja quando revisita cinejornais obscuros à procura de rastros das vidas de antilhanos emigrados na Inglaterra no seu primeiro documentário, As Canções de Handsworth (1986), toda a sua obra constitui uma negação da ideia do artista demiurgo, criador de mundos. Não sem razão, ela tem na figura do Ladrão de $\operatorname{Dados}^{1}$ um de seus personagens mais célebres.

Este cinema compósito, semeado por imagens alheias, devota uma obstinada atenção aos vestígios da presença negra na cultura visual. Ganês de nascimento,

\footnotetext{
10 Ladrão de Dados é o protagonista de "O Último Anjo da História" (1995), incursão de Akomfrah na ficção científica.
}

Dossiê Apropriações e ressignificações na arte e no pensamento - https://revistaecopos.eco.ufrj.br/ 
Akomfrah acha-se exilado em Londres com a família ainda na infância, nos anos 1960, quando sua vida se confunde com as tramas das migrações de outros milhares de africanos, caribenhos e asiáticos desembarcados na Grã-Bretanha. Essa experiência de deslocamento irá nortear toda a sua prática fílmica. Convidará a uma peregrinação outra, por diversos arquivos, na qual vai encontrar no uso de imagens do passado um meio para afirmar-se como artista. Em diversos trabalhos, Akomfrah retorna às memórias dos imigrantes que chegaram ao Reino Unido no pós-guerra, àquela que ficaria conhecida como "geração Windrush"2. Nessas obras, contempla a dispersão dos filhos das antigas colônias valendo-se dos materiais de arquivo para interrogar uma e outra vez as "condições caleidoscópicas da negritude" (BAILEY; HALL, 2003, p. 383, tradução nossa) em solo europeu. À medida em que sua história pessoal se vê imiscuída nos reflexos do colonialismo atualizados em uma Inglaterra hostil ao outro racial, os recuos ao passado permitiriam ao jovem realizador problematizar a amnésia britânica em torno da violência de sua história colonial e contestar concepções apriorísticas de categorias como raça, imigrante, negro. Não por acaso, em sua primeira obra, a slide-tape ${ }^{3}$ Signos do Império (1983), realizada junto ao coletivo Black Audio Film Collective, apropria-se de uma pletora de figuras do espólio visual imperialista, entre elas mapas, pinturas alegóricas, retratos etnográficos, caricaturas, fotografias de safáris e de prisioneiros de guerra, em vistas a desarticular as fantasias primitivistas projetadas sobre africanos e asiáticos, abrindo as fissuras necessárias nas narrativas subjacentes àquelas imagens para que elas pudessem ser reescritas.

\footnotetext{
2 Windrush" é o nome do vapor que que em junho de 1948 aportou em Essex repleto de antilhanos e cuja chegada funciona como uma espécie marco inaugural dos movimentos migratórios oriundos das ex-colônias britânicas à Inglaterra no pós-guerra.

3 Dispositivo recorrente na cena cultural artística das décadas 1970 e 1980, a slide-tape é uma projeção de slides de $35 \mathrm{~mm}$ acompanhada de trilha sonora sincronizada e, eventualmente, de improvisações ao vivo.
}

Dossiê Apropriações e ressignificações na arte e no pensamento - https://revistaecopos.eco.ufrj.br/ 
Na obra de Akomfrah, as imagens de arquivo funcionam como pistas dos sentidos submersos da experiência negra na Inglaterra, conjunto de vivências historicamente enredadas num emaranhado de apagamentos, malversações, projeções. Ao incorporar fragmentos das culturas midiática e vernacular, da história da arte e da literatura, o cineasta reaviva memórias diaspóricas em geral alijadas das raias da história oficial. 0 impulso em fazer falar aquilo que está silente, oculto no não-dito da história, convive com uma postura desassombrada perante as formas originárias dos materiais revisitados. Em seus trabalhos, as imagens de arquivo são arrancadas de contexto e forçosamente lançadas em um outro campo de relações. Destituídas da voz que originalmente lhe acompanhavam, tingidas com outras cores, justapostas a textos e dados visuais dessemelhantes, ao encontrar uma nova morada em seus filmes, as imagens sobrevêm seguidas manipulações. Como se Akomfrah professasse a cada reemprego o ideal de "tornar nativo e miraculosamente vivo o que é estrangeiro ou aparentemente arruinado" preconizado por Wilson Harris (1983, p.236, tradução nossa).

A tradição do reemprego de materiais preexistentes à qual Akomfrah se filia é tão antiga quanto o cinema. Dentre as inúmeras feições por ela assumida, nenhuma oferece ângulo tão privilegiado para ler a obra do artista britânico como a do filmeensaio. Embora arredia a uma definição consensual, a noção de "filme-ensaio" é comumente associada a uma forma argumentativa, às possiblidades de figurar processos do pensamento por meio da linguagem cinematográfica. Naturalmente, a outra qualidade própria ao ensaio fílmico sobre a qual gostaria de me deter é a sua verve apropriadora, o ímpeto de citar, comentar ou reempregar imagens e palavras assinadas por outrem. Trata-se de uma característica herdada do ensaísmo literário, cujos procedimentos em geral tendem a se distanciar da ideia romântica de criação original, da expressão de uma interioridade inimitável. Na observação medular de Lukács, o ensaio "sempre fala de algo já formado, ou, no melhor dos casos, de algo já existente; é próprio de sua natureza não extrair coisas novas do vazio" (2014, p.42), 
portanto, "o título de todo ensaio é precedido, em letras invisíveis, pelas palavras, 'Pensamentos ocasionados por..."' (Ibid, p.47). De modo similar, Max Bense descreve o ensaísta como um montador ambulante, um "combinador que cria incansavelmente novas configurações ao redor de um objeto dado" (2017, p.57). A visão de um sujeito atuando como um intercessor de criações alheias para exteriorizar ideias num fluxo de sons e imagens, mesmo sem jamais recorrer à primeira pessoa, sem externar um "eu”, me parece descrever com precisão a voz enunciativa dos filmes de Akomfrah.

Mais precisamente, o filme-ensaio é instrutivo pois as figurações do pensamento a ele associadas remetem a uma tensão formal determinante na obra do artista. Se em seus filmes os planos são em geral orquestrados a fim de concatenar "ideias", tal arranjo se vê ao mesmo tempo perturbado pela aparição de imagens não subordinadas aos encadeamentos discursivos. Temos assim criações ensaísticas que assimilam as derivas de imagens que parecem querer a todo instante desligar-se do fluxo retórico da montagem. De fato, por vezes, ao se assistir aos trabalhos de Akomfrah, têm-se a sensação de que a presença do cineasta-montador se esfuma e as imagens passam a percorrer seus próprios itinerários. Estética do fragmento na qual cada plano reclama a sua individualidade. $\mathrm{Ou}$, nos termos de Vincent Amiel, uma "montagem com dupla função, que insiste tanto na entidade de cada elemento como na combinação que eles formam" (2007, p.67). Este artigo quer explorar precisamente essa tensão entre discurso e deriva no cinema de Akomfrah. Num primeiro movimento, argumento que, antes de ser mera ferramenta numa teia discursiva, a imagem fílmica, por encerrar uma emanação do real, carrega consigo uma singularidade em parte irredutível aos desígnios da montagem. Na sequência, analiso os jogos associativos de As Canções de Handsworth, com o intuito de interrogar em que medida, mesmo nas aparições mais fugidias, a presença de imigrantes nos materiais de arquivo reempregados por Akomfrah seria portadora dos anseios e desenganos da experiência diaspórica na Inglaterra.

Dossiê Apropriações e ressignificações na arte e no pensamento - https://revistaecopos.eco.ufrj.br/ 
Em mais de uma ocasião, Akomfrah externou uma espécie de concepção animista da imagem fílmica, como se esta fosse dotada de vida e agências próprias e, em decorrência disto, o seu destino se encaminhasse muitas vezes à revelia de quem as criou ou de qualquer que tenha sido o seu uso original. Sob essa luz, reconhece-se "ligado ao tipo de estética do não intencional do vodun, à maneira pela qual as coisas têm a sua própria ontologia, sua própria vontade" (Akomfrah, 2018a, $\mathrm{s} / \mathrm{p}$, tradução nossa). Noutro viés, tal crença se traduz numa preocupação ética perante as figuras anônimas que um dia emprestaram suas imagens aos antigos cinejornais e documentários, dos quais o realizador não se cansa em se apropriar:

\begin{abstract}
Eu parto da suposição de que tudo o que eu uso ou me aproprio vem com uma nota promissória. 0 importante não é apenas as pessoas que estão fora dos materiais de arquivo; realizadores, operadores de câmara, etc., mas também as pessoas dentro do material. Todos aqueles que consentiram em ser filmados estão a dar ao futuro uma espécie de nota, dizendo "quando vir isto amanhã - sou eu". Tento encontrar quantas posso dessas notas promissórias e depois tenho que juntá-las, mas no presente. "Eu sei que disse que quer estar no futuro, mas gostaria de estar neste futuro com aquele tipo ou esta mulher?" Tenho que tentar seduzir cada fragmento para fazer uma promessa a outro fragmento, porque sem isso é impossível haver narrativa (Akomfrah, 2018b, s/p, tradução nossa).
\end{abstract}

Mais importante que suas falas públicas, é notar como o cinema de Akomfrah dialoga com as existências dos sujeitos filmados na superfície das imagens. 0 modo como procede a meticulosos reenquadramentos, convidando o olhar a demorar-se sobre determinado detalhe visual; a reiteração de um plano específico a percorrer diferentes filmes ou a repetição de certos motivos iconográficos por toda sua a obra, produzindo, a partir da recorrência, ligações estruturantes de sentido, evidenciam uma relação de perplexidade perante a imagem fotográfica. 0 fato desta surgir de uma emanação literal do referente (Barthes, 1984, p. 58), da impressão direta do real sobre o suporte sensível, isto é, a sua qualidade de índice, não cessou em inquietar a obra do artista.

Dossiê Apropriações e ressignificações na arte e no pensamento - https://revistaecopos.eco.ufrj.br/ 
Isto se manifesta em definitivo na forma como suas criações iluminam a presença diaspórica no arquivo visual. Mesmo quando sujeitos negros eram filmados por cinegrafistas europeus não raro indiferentes à complexidade de suas existências, o olho mecânico da câmera, parece nos dizer Akomfrah, pode ter legado um vestígio precioso sobre aquelas vidas. 0 trabalho dedicado à geração Windrush em As Canções de Handsworth é emblemático a esse respeito. Mergulhado no arquivo britânico do pós-guerra, Akomfrah parece partilhar espanto semelhante ao descrito por Roland Barthes diante de uma fotografia, o de ser absorvido no paradoxo entre uma proximidade espacial e uma distância no tempo. Ora, infere Barthes, a natureza documental da imagem fotográfica não é outra coisa senão o seu “caráter mágico" (1990, p.36); a sua realidade não é outra senão "a de ter estado aqui, pois há, em toda fotografia, a evidência sempre estarrecedora do isto aconteceu assim: temos, então, precioso milagre, uma realidade da qual estamos protegidos" (Ibid., loc. cit.). A obra de Akomfrah se presta a uma meditação continuada sobre essa qualidade enigmática do registro indicial. Como já mencionado, isto se reflete numa atenção minuciosa às informações visuais e historiográficas contidas em cada imagem do passado.

No entanto, deve-se ressaltar, há vezes em que Akomfrah toma a direção inversa, consagrando aos materiais de arquivo um uso puramente retórico. Refirome a procedimentos de condensação dos sentidos latentes na imagem, à qual a montagem atribui uma forte carga simbólica, como se a especificidade testemunhal do registro fotográfico fosse abstraída e ela se tornasse um significante genérico, transmutada em "conceito" ou "ideia”. A esse título, a figura da paisagem pastoral britânica é recorrente em seu cinema. Ela aparece seguidas vezes em $O$ projeto Stuart Hall (2013), documentário biográfico dedicado ao sociólogo jamaicano, referência inestimável para Akomfrah e a geração do cinema negro inglês surgida na década de 1980. Neste filme, as vistas pastoris parecem ressoar um texto do sociólogo que evoca a "imagem de uma verde e agradável terra inglesa, com seu doce e tranquilo interior, com seus chalés de treliças e jardins campestres" (Hall, 2006, 
p.31), cujo papel, observa Hall, é atuar como elo unificador na narrativa da nação, o tipo de signo-mestre que conecta as vidas isoladas de membros de uma mesma comunidade nacional. A harmonia e a paz conotadas pelo motivo ganham em Akomfrah um tratamento irônico. Vemos no filme uma sequência de imagens campestres a culminar num plano de vacas pastando [Fig.1-3], acúmulo de dados simbólicos de britanidade logo perturbado pela narração de Hall, cuja voz, retirada de um antigo programa de rádio, anuncia: “O 'Panorama' de hoje está dedicando todo o tempo a um assunto: a Bomba H". Tal método associativo remete à montagem intelectual teorizada por Eisenstein (1990), segundo a qual cada plano deve ser reduzido a um dado informacional, funcionando à maneira de um sinal pictográfico, um hieróglifo, e a partir da combinação entre eles, o filme se desenrolaria numa sequência de proposições discursivas. No caso referido, a partir da relação textoimagem, intui-se rapidamente o conluio entre a ideia de orgulho nacional e a participação do Reino Unido nos enredos políticos da Guerra Fria, tema abordado noutras passagens do documentário. Noutro momento, a fala de Hall articula vivências pessoais e coletivas do racismo na Inglaterra, palavras justapostas, no plano visual, à aparição de muros onde lê-se "Mantenha a África negra/Mantenha a Grã-Bretanha branca" e "Negros vão para casa" [Fig.4-5]. Logo a seguir, vemos retornar o motivo das vacas no pasto. Desta vez, no entanto, à sombra das reflexões pregressas do teórico acerca da cultura britânica, observada por ele no filme em suas raízes arcaicas, etnocêntricas, e em suas reações hostis à chegada de imigrantes negros, vemos na imagem não a bonança anterior, senão animais saltando irritadiços à presença da revoada pássaros que agora povoa paisagem [Fig.6]. 

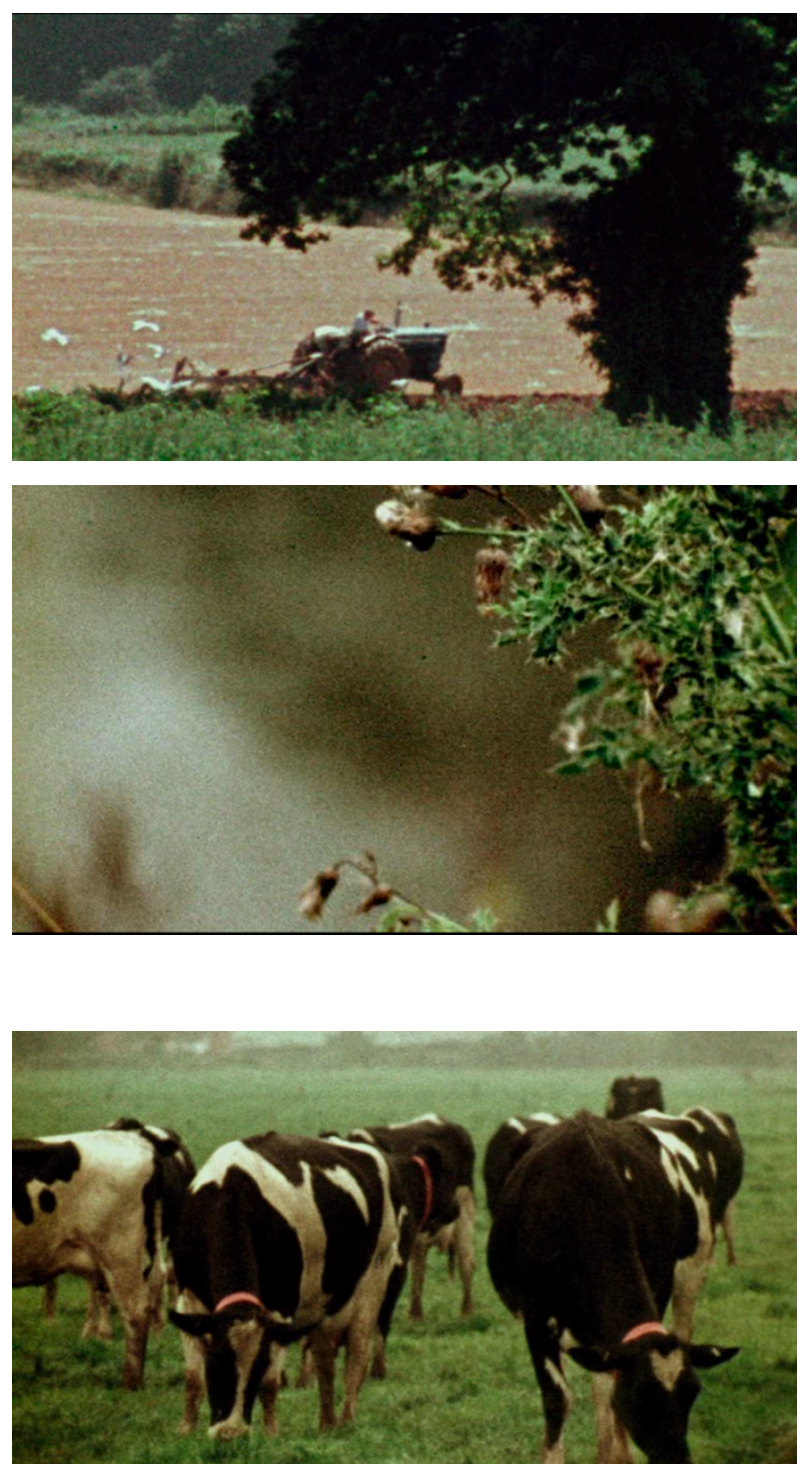

Figuras 1-3

O Projeto Stuart Hall. John Akomfrah, Reino Unido, 2013

Dossiê Apropriações e ressignificações na arte e no pensamento - https://revistaecopos.eco.ufrj.br/ ISSN 2175-8689 - v. 24, n. 3, 2021 

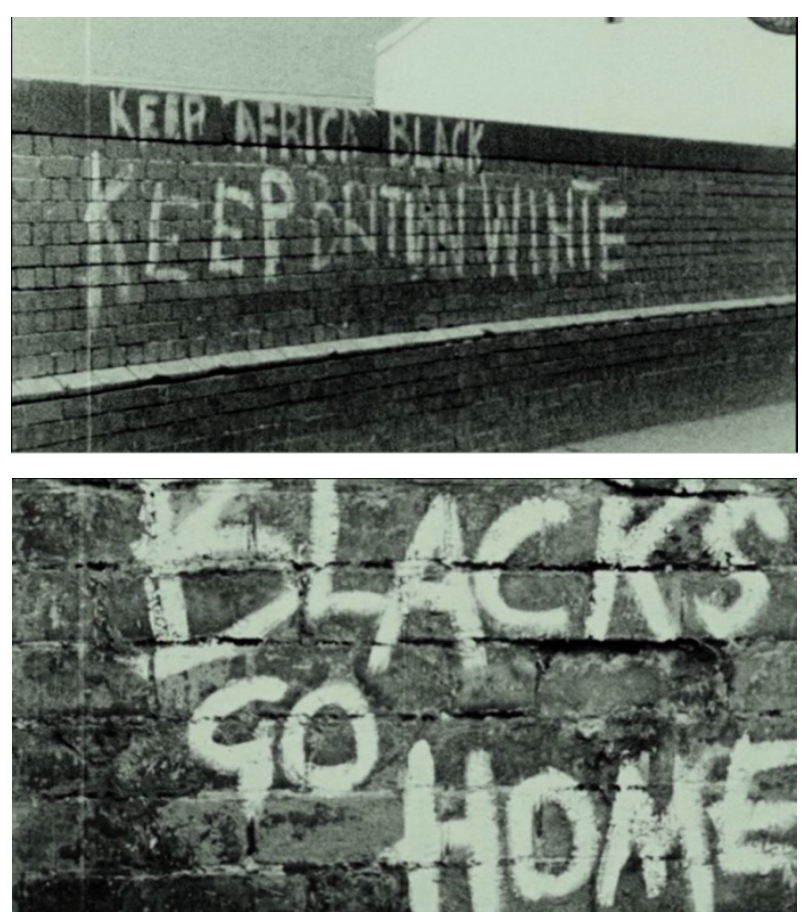

Figuras 4-5

O Projeto Stuart Hall (2003)

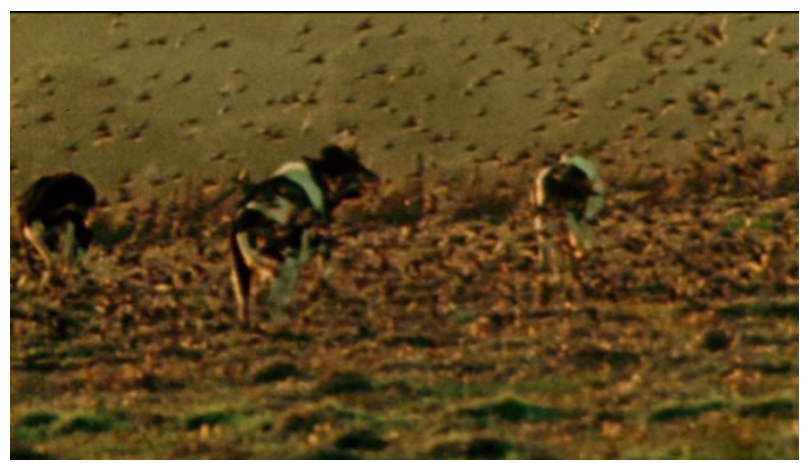

Figura 6

O Projeto Stuart Hall (2003)

Curiosamente, a montagem descrita acima tende a complicar o potencial revelatório da imagem fotográfica tantas vezes exaltado por Akomfrah. Uma vez inserida em tal ordem de manipulação retórica, a realidade duplicada pelo fragmento fílmico e toda a sua possível estranheza parecem se esvair numa cadeia

Dossiê Apropriações e ressignificações na arte e no pensamento - https://revistaecopos.eco.ufrj.br/

ISSN 2175-8689 - v. 24, n. 3, 2021

DOI: 10.29146/ecopos.v24i3.27766 
de manobras discursivas. De fato, se considerarmos os críticos céticos quanto ao valor do rastro indicial, constatamos que qualquer que seja o teor dos planos filmados, ele será adiante diluído nos encadeamentos da montagem, manipulado por relações de sentido produzidas a posteriori por meio do corte. Muito pouco restaria assim a ser aferido à marca evidenciária do índice.

$\mathrm{Na}$ verdade, o lado problemático da crença na fidelidade descritiva do cinema, em sua suposta capacidade em inscrever objetivamente o real e, portanto, documentar o mundo, começa no próprio momento do registro. Como sabemos, filmar implica selecionar e recortar, portanto, excluir. A janela cinematográfica é sempre um quadro que exclui, o olhar impassível da câmera vê sempre aquilo que lhe ordenam ver, responde invariavelmente ao comando do cinegrafista, esquadrinhando apenas a porção do mundo que este sente-se instando a buscar (Rancière, 2014, p.31-32). A imagem fotográfica seria assim menos reprodução imaculada do real do que subproduto de uma vontade de discurso. Na síntese de Jean-Louis Comolli “o polo considerado 'objetivo' (ainda que saibamos ser uma ilusão) está de fato instrumentalizado pelo polo subjetivo" (2012, p. 115-116, tradução nossa). Toda ordem de intenções, imperativos, interesses, lógicas concorrem para eleger o que é ou não merecedor de estar no enquadramento. Assim, o mundo visto na tela será sempre e tão somente o mundo filmável, aquele que está destinado a ser convertido em filme (Ibid., p. 117). Do outro lado, claro, restam os mundos não filmáveis, as imagens que jamais vieram a existir, os vestígios ausentes.

As diversas variantes do cinema de apropriação, no entanto, irão contestar a intencionalidade e a as manipulações do conteúdo filmado, liberando as imagens de suas funções e encadeamentos originários, produzindo inumeráveis desvios e inversões. Não apenas isso, o jogo do reemprego nem sempre obedece ao tipo de montagem eisensteiniana, empenhada em obter o mais eficaz controle do sentido. A obra de Akomfrah é exemplo disso. Embora recorra a procedimentos notabilizados pelo mestre russo, como observado em O Projeto Stuart Hall (2013), de modo geral, 
ela contraria suas ideias. No mais das vezes, seus filmes permitem uma flutuação mais livre do fragmento, acentuando as ambivalências do documento apropriado, afastando-o assim de moldes retóricos coercivos.

Não só em Akomfrah, as linguagens apropriacionistas em geral se definem pelo impulso em relativizar o caráter arbitrário no coração da prática cinematográfica. É como se a cada nova apropriação o artista lembrasse ao cineasta de quem empresta os materiais de que ele não é o senhor absoluto do real captado pela câmera, sendo ele também visado pelo mundo, pelas pessoas que o habitam, pelas intrusões do acaso. Haveria, portanto, uma mise-en-scène do mundo e uma auto-mise-en-scène do sujeito filmado que tensionariam toda a ambição de controle por parte do cinegrafista (Comolli, 2008). 0 corpo filmado, em especial, está sempre a performar a si mesmo e a disputar a sua aparição no quadro. Tal corpo, observa Comolli, "na medida em que é o de um sujeito que deseja, dirige à máquina uma mensagem silenciosa que constitui sua maneira de integrá-la ao seu campo mental [...] O corpo filmado entra num processo de auto-mise-en-scène, que é o que a máquina registra" (Ibid., p. 109-110). Naturalmente, essa relação de forças é acentuada na forma documentária, em sua relativa abertura ao outro e aos movimentos não roteirizados da vida. A busca por identificar pequenos instantes de "rebelião", por encontrar uma surpresa fecunda na relação entre o cinegrafista, o plano e o acontecimento filmado, é uma constante na obra de realizadores devotados ao arquivo.

Haveria afinal, à revelia de toda manipulação, um quê de indeterminado no vestígio indicial. Rancière examina essa questão ao comparar o cinema às outras artes, atribuindo à natureza mecânica do registro fílmico a sua, por assim dizer, "modernidade espontânea". No juízo do pensador francês, seria "natural" à câmera lograr aquilo a que as literaturas modernas aspiravam e apenas a muito custo poderiam conseguir: "a igualdade entre um processo consciente e um processo inconsciente" (Rancière, 2014, p.20, tradução nossa). Noutra frente, Comolli desdobra o problema do índice ao insinuar a existência de um "diálogo direto entre 
o acontecimento e o filme" (2012, p.123, tradução nossa), pensando numa leitura futura apta a decifrá-lo. 0 sentido desse encontro entre o real e a imagem que se faz dele, argumenta, é com frequência ignorado pelo operador da câmera, o diretor, o montador, e mesmo o espectador contemporâneo ao filme. Do índice emanaria assim uma relativa opacidade, como se ele carregasse em si "a promessa de um sentido" (Ibid.p.123, tradução nossa), uma nota promissória remetida ao porvir.

0 cinema enraizado no arquivo lidou com a inquietante ambivalência da marca cinematográfica, o seu excesso, o "defeito paradoxal[...]de mostrar demais" (Rancière, 2014, p.231, tradução nossa), de inúmeras maneiras, entre as quais sobressaem duas correntes predominantes. Por um lado, tenta-se restituir o gesto originário de criação da imagem, quem a filmou, em que data, sob qual pretexto, quais as camadas de interpretação a ela sobrepostas no curso da história, as representações a ele associadas, as disputas de sentido. Comum a inúmeros documentaristas, tal método tem em Harun Farocki o seu adepto mais notável. Na outra vertente, ao contrário, a história por trás da imagem é tornada rarefeita, quando não de todo abstraída, e a imagem passa a valer mais por sua existência enquanto cinema, acentuadas as suas qualidades plásticas e as suas entonações afetivas. Diversos artistas alinhados a essa segunda tendência celebram a individualidade do fragmento ao assimilá-lo em criações estritamente visuais, sem quaisquer cartelas, intertítulos, narração, e não raro enfatizam o gesto apropriador no momento de creditar as fontes, preferindo citar o arquivo consultado em vez do diretor ou ator/atriz em cena. Essa segunda escola se firma numa espécie de poética do rastro indicial; em seus filmes, argumenta Catherine Russell, "somos imersos não em informação, mas em sensação, movimento e espaço" (2018, p.47, tradução nossa). A ela se filiam os cinemas de Douglas Gordon, parte das obras de Godard e Kevin Jerome Everson, Ken Jacobs, Yervant Gianikian e Angela Ricci Lucchi e muitos outros, entre eles Akomfrah.

Na obra do artista britânico, a relativa desobrigação do contexto, o esvaziamento de estrutura narrativa ou discursiva bem definidas, decorre de uma 
fé no fragmento, no renitente mistério das imagens cinematográficas. Em contrapartida, é imperioso remontá-las, colocá-las em contato com outros signos, palavras, dados, para que os vestígios nelas contidas venham à luz. 0 cinema de Akomfrah se equilibra entre o culto ao fragmento e o apelo à montagem. Enquanto esta se fia na forma ensaística, na aspiração a um "cinema de ideias" (Eshun, 2007, p.96, tradução nossa), aquele quer restituir um valor aurático à imagem, lendo em cada uma delas o índice de uma história oculta merecedora da mais urgente atenção no presente. Essa relação pendular permeia toda a obra do artista, a começar por suas criações realizadas junto ao coletivo Black Audio Film Collective.

Com As Canções de Handsworth Akomfrah testa pela primeira vez os jogos associativos da montagem para absorver e retrabalhar um conjunto de memórias afrodiaspóricas. Filme inaugural do Black Audio Film Collective, ele seria lançado um ano após uma série de levantes raciais irromperem em Handsworth e outros bairros negros de Birmingham. Akomfrah estava na cidade durante as revoltas. Embora não tivesse então qualquer projeto em mente, rodaria ali os primeiros planos posteriormente incluídos em As Canções de Handsworth. A princípio, aqueles registros não tencionavam mais que se somar à prática mais ou menos dispersa dos membros do Black Audio em filmar a realidade das comunidades negras britânicas, a fim de constituir um acervo próprio com imagens do presente. Contudo, uma vez em Birmingham, o diretor se dá conta de que captar os rescaldos dos protestos era de todo insuficiente. Nas palavras de Akomfrah, havia ali "uma temporalidade sombria" (2012, p. 107, tradução nossa) que exigia ser retrabalhada também por meio do arquivo, impelindo-o a pesquisar imagens de imigrantes radicados na GrãBretanha do pós-guerra emprestadas de acervos e coleções diversos. 
Nos registros filmados por Akomfrah, ouvimos diversos personagens de uma forma ou de outra envolvidos nos protestos: jovens de ascendência jamaicana, líderes indianos filiados aos partidos Trabalhista e Conservador, o ministro da informação, entre outros. 0 método da entrevista constitui uma das estratégias usadas pelo documentário para retratar a diáspora sob o thatcherismo. Nesse sentido, há, da parte de Akomfrah, uma insistência em questionar o estopim das revoltas, à qual os sujeitos filmados reagem com explicações quase sempre inconclusivas. Persiste, no entanto, o ato de perguntar. É ele que interessa. Como se a repetição da pergunta evidenciasse - também na própria incompletude das respostas colhidas - a indisponibilidade dos fatos imediatos em tornarem legíveis as razões por detrás dos levantes. Com efeito, As Canções de Handsworth busca as subcorrentes históricas do acontecimento, mas não no sentido de restituir uma causalidade de tipo sociológica apta a tornar transparente a trama complexa envolvendo a dispersão de caribenhos, africanos, indianos e paquistaneses pelo Reino Unido. Há, no recuo ao arquivo, a aposta numa paisagem afetiva, a busca por contemplar o desejo inicial daqueles imigrantes, cujas expectativas o filme contrasta a todo tempo com a violência dos confrontos com a polícia e sua respectiva cobertura midiática.

Em diversos momentos, As Canções de Handsworth incorpora um diálogo reflexivo em torno das representações dos levantes. Umas das formas pelas quais isto se evidencia é o modo como planos de câmeras em ação, no mais das vezes empunhadas por brancos, ressurgem seguidas vezes no filme. Dispositivos de vigilância, máquinas fotográficas, filmadoras de vídeo, cada um desses objetos é escrutinado por Akomfrah [Fig.7]. Em geral, enquadra-os em planos cerrados, de modo a destacar do emaranhado de eventos no entorno o instrumento e o gesto de filmar. Há nessa reiteração um aceno aos meios pelos quais as tecnologias da imagem configuram a realidade social e, de especial interesse para Akomfrah, a como as representações por elas produzidas disciplinam os sentidos de nação, 
britanidade, identidade. Conforme ouvimos da narração em voz over, estava em jogo "a guerra de nomear o problema", o qual os meios hegemônicos não demoraram a fixar sob o signo do "preto da desordem e do caos".

0 viés da cobertura dos protestos em Birmingham é confrontado cedo em $A s$ Canções de Handsworth. Numa sequência, vemos uma montagem composta de uma sucessão de fragmentos de jornal em cujas páginas as revoltas são reportadas em manchetes do tipo: “Ódio, frustração e destruição...”; “Campo de batalha sangrento”; "Revolta da morte" [Fig.8]; "Tocha de ódio" [Fig.9]; "O coração ensanguentado da Inglaterra" [Fig.10]; "Handsworth em chamas"; "Lutas raciais podem tomar conta da cidade"; "Não deixe ninguém falar disso como um levante racial. Essa criminalidade assassina não tem a ver com ascendência, genes e pátria".

Logo a seguir, os índices de confronto são substituídos pela visão de fotografias de casamento de casais negros [Fig.10]. Sobrepostas a um fundo escuro, as fotos são percorridas lentamente pela câmera, como se o seu movimento monumentalizasse os instantes nela retratados ${ }^{4}$. Esse dispositivo de fotografias vernaculares instaladas num fundo infinito aparece mais vezes em As Canções de Handsworth. Nesta primeira ocasião, ele é sucedido por uma série de imagens de arquivo, nas quais se alternam planos de casais negros em trajes formais dançando entre si, sendo cortejados por homens e mulheres brancos, e, mais adiante, por outros aparentemente filmados em paisagens rurais do Caribe: um homem trabalhando num canavial, um mulher lavando roupa no leito de um rio, outra dando banho num bebê em um balde metálico [Fig.12]. Toda a sequência é acompanhada da seguinte narração em voz over:

Ele disse a ela: "Lembra-se de Bernie Enriquez, Greta Borgue e Lady Jul Baccha? Lembra-se da condessa Coblansco, com sua blusa de veludo preta, sua saia de cetim estampada? Lembra-se das noites de coquetéis de rum Coruba e de sour de Coruba, de gravidezes secretas, de você molhada, amamentando, e eu lavando fraldas? É hora de termos nosso próprio filho.

${ }^{4}$ Sobre a relação entre fotografia e monumento nas obras do Black Audio Film Collective, ver Eshun (2007)

Dossiê Apropriações e ressignificações na arte e no pensamento - https://revistaecopos.eco.ufrj.br/ 
Nosso próprio senhor. George Hammond Banner Bart". Naquela noite, passei de uma ideia para uma possibilidade. Eu nasci num momento de inocência.

Neste excerto efetua-se uma passagem do discurso público midiático à vida interior dos imigrantes. Tal movimento de um relato a outro, de uma época à outra, é estruturante em As Canções de Handsworth. Aqui, o tratamento histérico conferido às revoltas pela imprensa se vê infiltrado pela cotidianidade de dados vivenciais da geração Windrush na Inglaterra: fotografias de casamento, os bailes de gala, o gosto pelo rum Coruba. Mas há ainda o canavial caribenho, a precariedade do trabalho no campo, os trajes leves, o sol escaldante. Nos interstícios entre um figurino e outro, entre uma paisagem e outra, insinuam-se os fluxos do desejo. Há, nessa passagem do estereótipo ao íntimo, uma escuta aos liames do amor romântico, o espaço dos flertes, a sedução recatada dos bailes, a espera de um filho.

Esse recuo às memórias caribenhas ilumina a parte faltante do quadro das sublevações em Birmingham. Se o passado colonial, com os vínculos que unem a Inglaterra às Antilhas, é a narrativa ausente que doa sentido às revoltas dos anos 1980, Akomfrah vai torná-la visível ao remeter ao arquivo. Irá trabalhar sobre o "real", o acontecimento, os protestos, mas o fará também a partir das superfícies discursivas e estratos históricos que constituíam e acirravam o conflito no presente. Em As Canções de Handsworth, a memória, por assim dizer, opera o levante.

Conforme ilustrado pela passagem comentada acima, isso se dará não pela via dos nexos causais ou da linearidade cronológica, senão por uma errância ensaística a percorrer a relação entre as imagens e entre estas e as palavras. Na obra de Akomfrah, as imagens de arquivo são apenas o começo, elas portam verdades sempre parciais, incompletas, as quais o corte e o discurso verbal irão articular. A elaboração remissiva de seus filmes, cujas digressões embaralham tempos e pontos de vista distintos, e nas quais abundam citações, suscita uma busca pelo sentido latente nos intervalos, nos movimentos de disjunção e agrupamento operados pela 
montagem. Lacunar, fragmentária, a estrutura de suas criações convida-nos a fruílas ativamente. Nesse sentido, numa apreciação do filme-ensaio ligado às linguagens apropriacionistas, reunidas sob a rubrica da "arquiveologia", Cathernie Russell argumenta que essa vertente busca meios de precipitar uma reciprocidade fecunda entre passado e presente cujos efeitos se fariam sentir, potencialmente, numa pedagogia do olhar, na proliferação de novas modalidades de leitura: "uma das principais características da arquiveologia é que ela produz uma forma crítica de reconhecimento. 0 espectador é capaz de ler as imagens, mesmo que sua origem nem sempre seja exatamente clara" (2018, p.22, tradução nossa). Noutra passagem evocativa das montagens elípticas de Akomfrah, ressalta que práticas de reemprego por ela analisadas trabalham o fora-de-campo em sentido forte, suturando o "visível e o invisível", como se nos lembrasse a todo momento de que "fora de cada fotograma do fragmento arquiveológico há um conjunto de pessoas, tecnologias, geografias e histórias" (Ibid, 2018, p.220, tradução nossa).
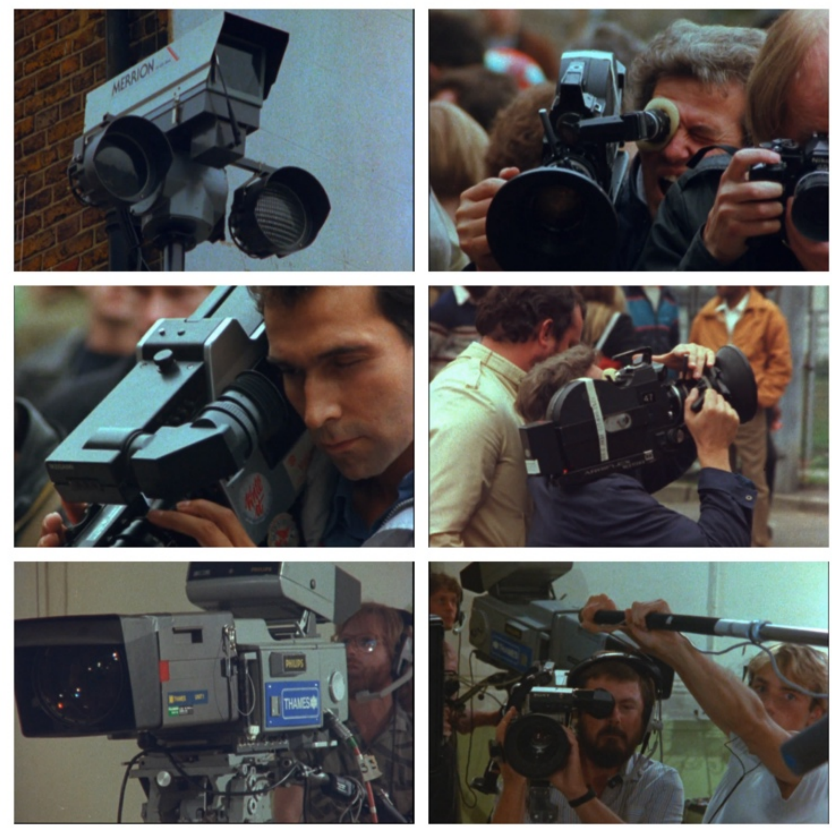

Figura 7

As Canções de Handsworth. John Akomfrah, Reino Unido, 1986

Dossiê Apropriações e ressignificações na arte e no pensamento - https://revistaecopos.eco.ufrj.br/ ISSN 2175-8689 - v. 24, n. 3, 2021 


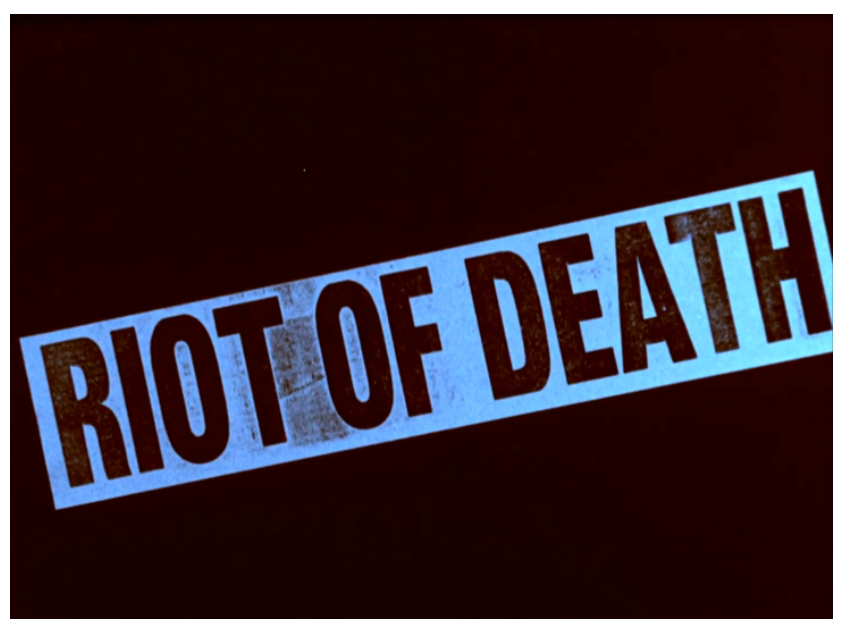

Figura 8

As Canções de Handsworth

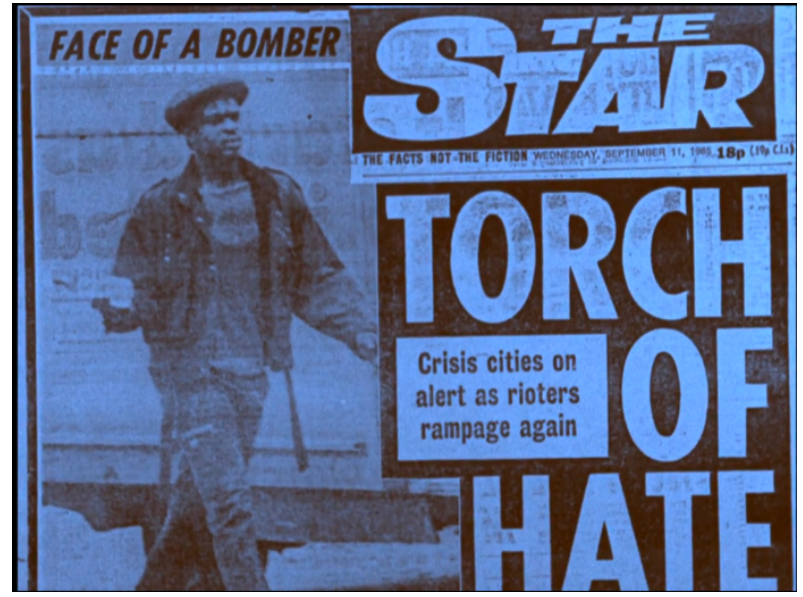

Figura 9

As Canções de Handsworth

Dossiê Apropriações e ressignificações na arte e no pensamento - https://revistaecopos.eco.ufrj.br/

ISSN 2175-8689 - v. 24, n. 3, 2021

DOI: 10.29146/ecopos.v24i3.27766 


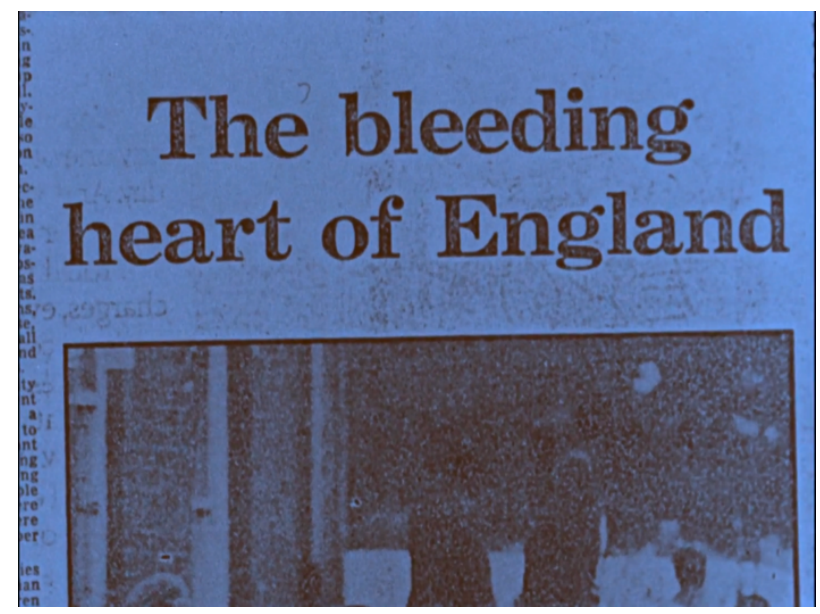

Figura 10

As Canções de Handsworth

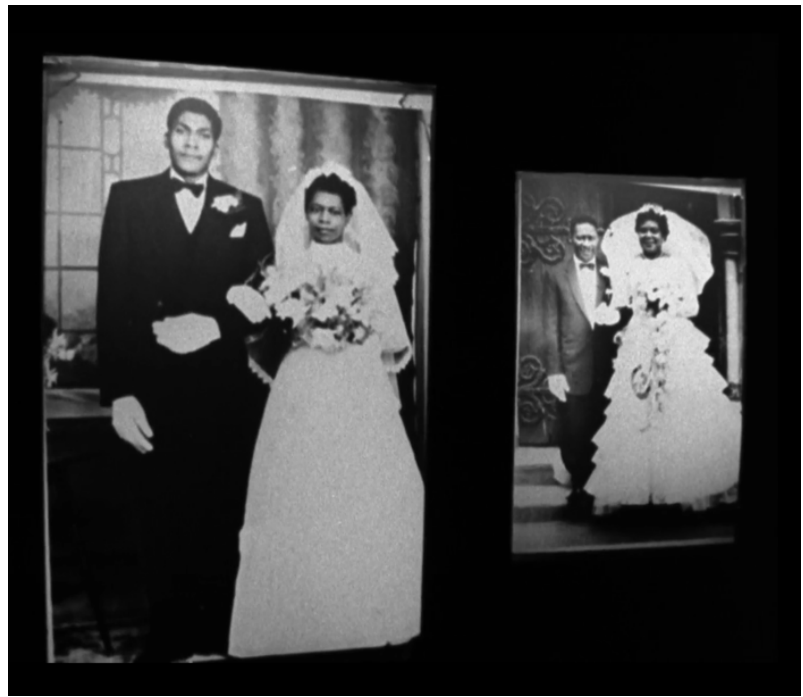

Figura 11

As Canções de Handsworth

Dossiê Apropriações e ressignificações na arte e no pensamento - https://revistaecopos.eco.ufrj.br/

ISSN 2175-8689 - v. 24, n. 3, 2021

DOI: 10.29146/ecopos.v24i3.27766 

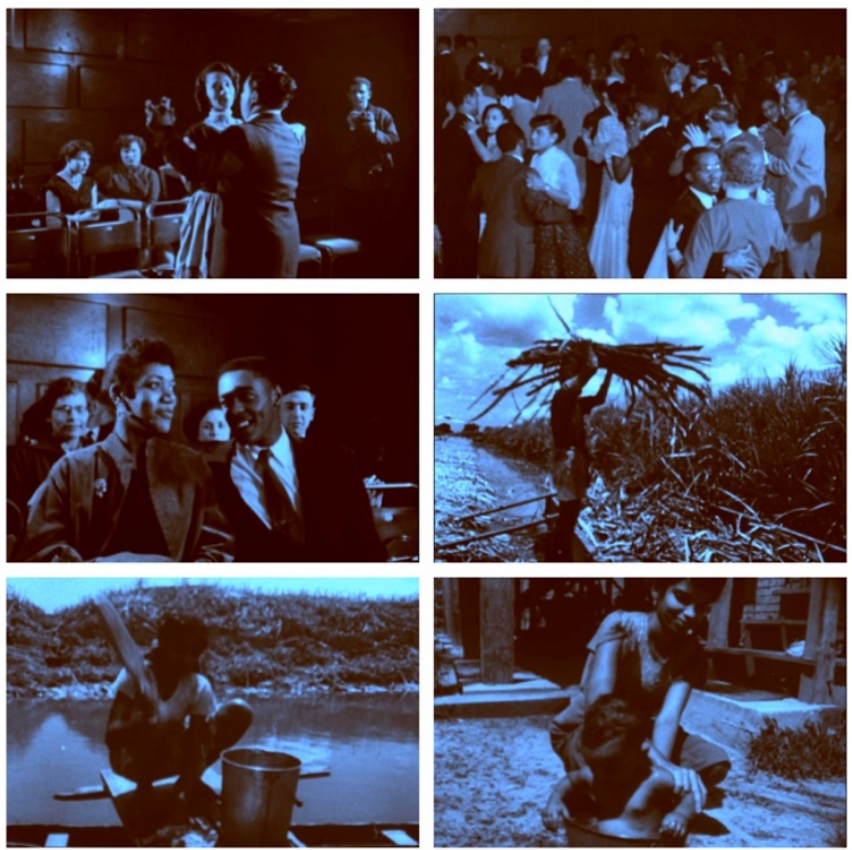

Figura 12

As Canções de Handsworth

Em seus estudos de referência acerca das migrações transnacionais no cinema, Laura Marks (2000) e Hamid Faficy (1993) observam que autores cujos filmes se ocupam em retratar a própria experiência de desenraizamento tendem a ostentar uma relação fetichista com as imagens ligadas às suas culturas de origem. Em As Canções de Handsworth nota-se precisamente o inverso. Se há no filme uma imagem-fetiche é a do desembarque, registro visual da chegada de caribenhos nos portos britânicos do pós-guerra. Povoadas de crianças e adultos, grupos de rapazes e famílias inteiras, em cores ou preto e branco, essas vistas retornam a todo instante no filme [Fig.13]. A figura recorrente do desembarque acentua a dimensão do desejo do imigrante - "Londres, este é o meu lugar", ouvimos cantar o ícone do calypso Lord Kitchener na proa de um navio [Fig.14]. Ela sintetiza o êxtase da chegada, a impressão inicial de uma paisagem nova descortinada do convés, índices do impulso em estar ali, das expectativas e ambições que antecedem a um posterior 
estranhamento. Afinal, muitos antilhanos não desfrutariam da hospitalidade que imaginavam encontrar no Reino Unido. No contexto das relações raciais na Inglaterra durante os anos 1960, Stuart Hall afirma que a condição dos nativos das ex-colônias se debatia entre a "aceitação formal e segregação informal” (1967, p.10, tradução nossa). Placas de senhorios locais com os dizeres "Não aos irlandeses, não aos negros, e não aos cachorros" encontrados à época ou o slogan "Mantenha a GrãBretanha Branca", sugerido por Winston Churchill na campanha eleitoral de 1955, dão o tom da hostilidade xenófoba e racista que grassava pelo país.

Se o recurso às imagens de arquivo é uma constante em As Canções de Handsworth, nada nos é informado sobre suas fontes ou o modo como circularam e foram recebidas no tempo de sua feitura ${ }^{5}$. Todavia, ao abstrair a origem dos materiais apropriados, Akomfrah não abstrai de todo a sua historicidade. Resta, afinal, alguma inteligibilidade do tempo histórico, pois o filme salta a todo momento dos protestos envolvendo jovens caribenhos para planos mostrando aqueles que bem poderiam ser seus familiares aportando décadas antes na Inglaterra. Ao adotar a forma ensaística, em que imagens, textos, vozes e ruídos heterogêneos se entrechocam para compor um painel polifônico da diáspora negra britânica, Akomfrah renuncia ao objetivo de ocupar uma função historiográfica tradicional, interrogando o arquivo não exatamente à busca de informações. Assim, os cinejornais e documentários revisitados lhe são valiosos não tanto por serem testemunhos de fatos, senão de sentimentos. Ao remontá-los, é como se o seu filme aspirasse a uma outra modalidade de história, buscando uma narrativa das percepções, um catálogo afetivo da geração Windrush. Em certa medida, opera-se no filme um desvio da modalidade de documento encarnada pelo testemunho calcada na fala, na entrevista, no universo verbal - para um outro registro firmado

\footnotetext{
${ }^{5}$ Em As Canções de Handsworth não são creditados o título ou o diretor de nenhum dos filmes dos quais empresta imagens. Apenas os arquivos consultados aparecem nos créditos. Quatorze anos mais tarde, ao revisitar as memórias da geração Winrush em As Nove Musas (2010), Akomfrah iria na direção inversa, mencionando nos créditos o autor e o título de cada obra da qual extrai fragmentos.
} 
na superfície, no aspecto antes de tudo visual - gestos, olhares, movimentos, vestuário, disposição dos corpos - das imagens reempregadas. Afinal, em As Canções de Handsworth, à exceção de Lord Kichener, não escutamos qualquer depoimento dos imigrantes negros que vemos chegar seguidas vezes nos portos britânicos. Mais que a fala, Akomfrah prefere legar um vislumbre de como aqueles olhos viram a terra nova aonde estavam prestes a desembarcar.

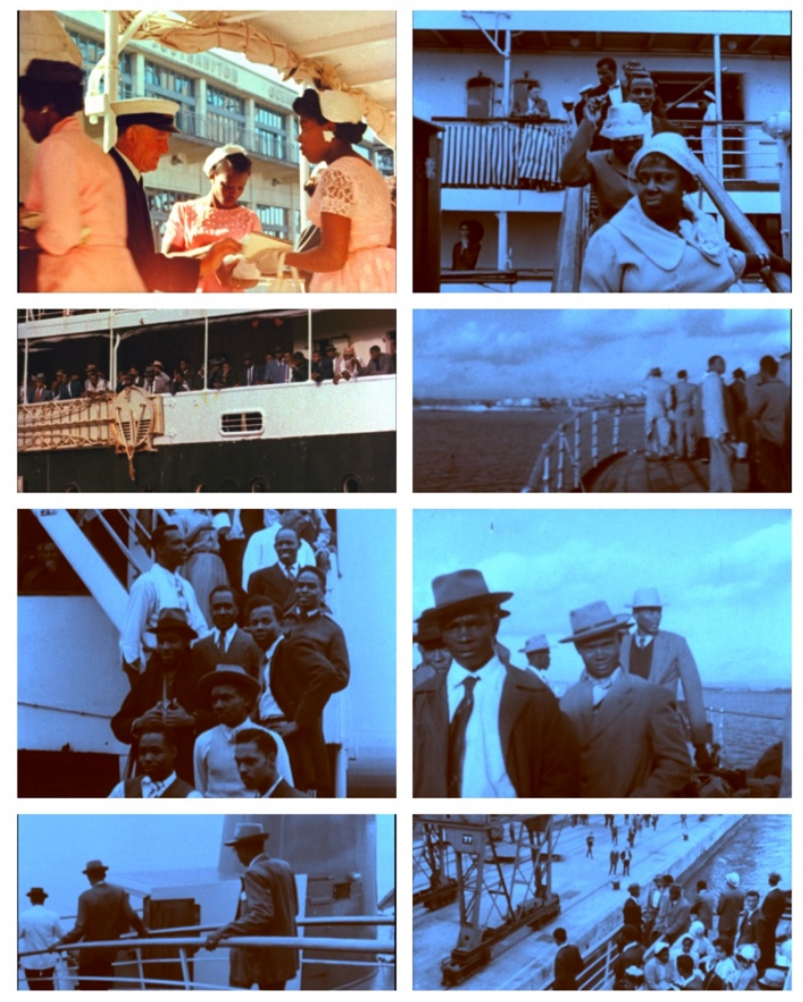

Figura 13

As Canções de Handsworth

Dossiê Apropriações e ressignificações na arte e no pensamento - https://revistaecopos.eco.ufrj.br/ ISSN 2175-8689 - v. 24, n. 3, 2021 


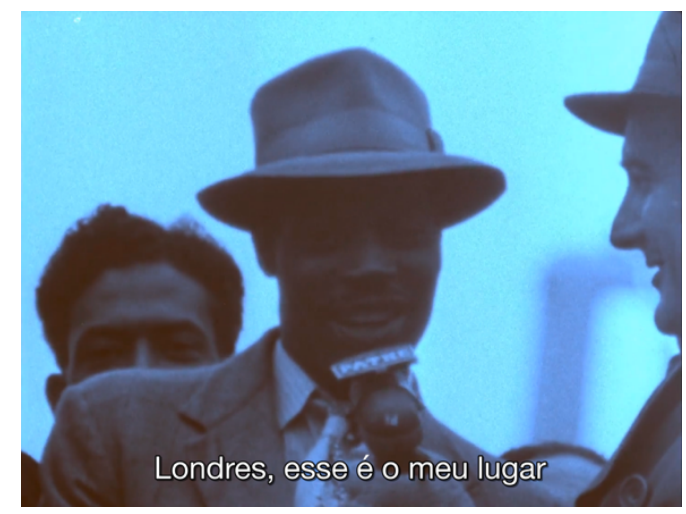

Figura 14

As Canções de Handsworth

De par com a cena dos desembarques, Akomfrah parece obstinado em iluminar os modos pelos quais o arquivo visual incorporou a presença do sujeito diaspórico nos cenários urbanos do Reino Unido. 0 jogo de apropriações em $A s$ Canções de Handsworth enfoca o trânsito de homens e mulheres negros em espaços públicos variados: canteiros de obras, fábricas, bailes, igrejas, escolas, ônibus, feiras. Se, como vimos, o artista reconhece nos materiais de arquivo incompletude, latência, diferença, tal leitura se reflete na forma de montá-los: um encadeamento muitas vezes elíptico, poroso, nos quais os fragmentos parecem flutuar solitários, desancorados de um contexto e mesmo de ligações fortes com os outros planos do filme, como a permitir que "as imagens falem no seu próprio idioma” (Russell, 2018, p. 22, tradução nossa). Essa relativa autonomia do fragmento encontra um de seus instantes mais pungentes num plano filmado no interior de um trem. Nota-se, ali, a princípio, nada mais que as vistas da cidade passando velozes ao movimento da locomotiva até que, pouco a pouco, insinua-se, refletida na janela, a figura de uma mulher negra a contemplar o caminho [Fig.15]. O plano dura apenas alguns segundos, mas toda a força plástica e a cintilação afetiva atribuídas ao rastro fotográfico parecem cobrar sentido quando a imagem daquela imigrante caribenha e a da paisagem britânica acidentalmente se fundem. 0 reflexo da mulher na janela, 
embora não seja operado pela montagem, remete à técnica fílmica da fusão, à dissolução de um plano sobreposto ao outro, e o leitmotiv do trem, análogo histórico do dispositivo cinematográfico, é também evocado na presença daquela imagem, para a qual as pesquisas no arquivo empreendidas por Akomfrah parecem querer reivindicar um lugar na história do cinema.

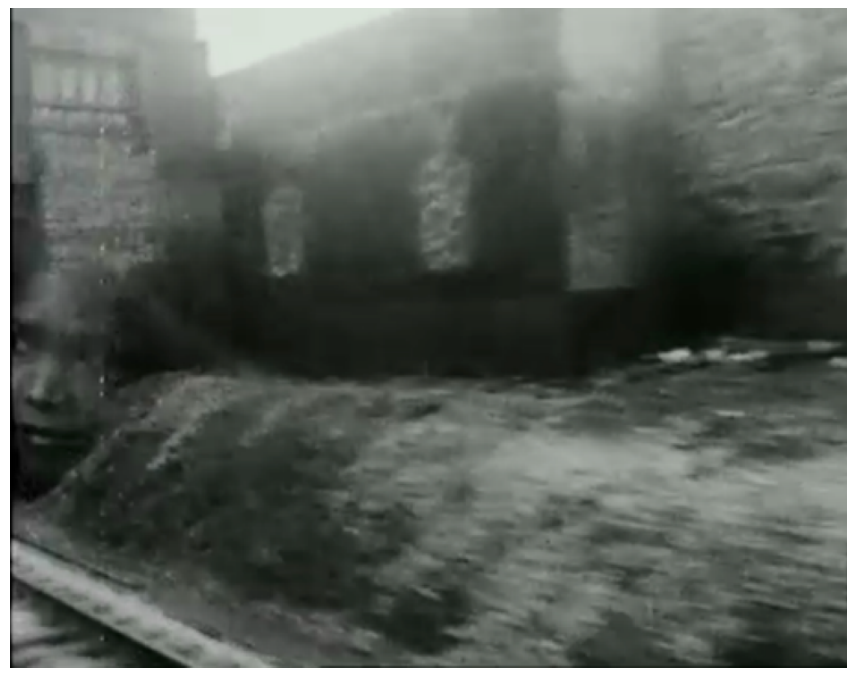

Figura 15

As Canções de Handsworth

O diálogo entre a atualidade turbulenta das vidas migrantes e a anterioridade do arquivo se dá a ver não apenas na justaposição de imagens, mas também na textura aural de As Canções de Handsworth. Assinado por Trevor Mathison, o desenho sonoro do filme é uma tapeçaria acústica densamente manipulada, composta por excertos de dub, reggae e canções indianas, bem como ruídos estilizados emitidos por revoadas de pássaros e baleias jubarte, ou ainda citações irônicas ao hino britânico "Jerusalem6". As ambiências complexas desenhadas por

\footnotetext{
${ }^{6}$ Hino nacional informal na Inglaterra, "Jerusalém" foi composto por Hubert Parry em 1906. Dez anos depois, Parry acrescentaria à música versos de William Blake escritos originalmente em 1806. 0 hino deve sua enorme popularidade à sua circulação massiva durante a Primeira Guerra Mundial. Os versos de Blake musicados por Parry compõem uma das mais célebres evocações da paisagem campestre da Grã-Bretanha pré-industrial.
}

Dossiê Apropriações e ressignificações na arte e no pensamento - https://revistaecopos.eco.ufrj.br/ 
Mathison acentuam a tonalidade afetiva das imagens do passado inventariadas por Akomfrah, deslocando-as a todo tempo em novas direções. Nesse sentido, se, conforme lamenta Catherine Russel, a banda sonora costuma ser um elemento suavizador da descontinuidade própria à linguagem arquiveológica (2018, p. 220), As Canções de Handsworth representa notável exceção. No filme de Akomfrah, o fluxo acústico intensifica choques tanto nos encadeamentos da montagem, como na justaposição entre imagem e som no interior do quadro, de modo que raramente nota-se uma domesticação do visual pelo sonoro. Com frequência, a organização dos ruídos perturba o sentido dos planos, conferindo-lhe estranheza e desconforto. A esse título, reiterados à exaustão, ruídos metálicos evocativos do maquinário industrial tingem com uma aspereza lúgubre as cenas dos desembarques de caribenhos nos portos ingleses. Desta forma, em diversas passagens é como se "as crueldades do devir político" aludidas pela narração em voz over encontrassem intensidades outras, não-discursivas, nos sons forjados por Mathison.

A acentuação aural infundida em As Canções de Handsworth é não raro sutil, quase imperceptível, mas seus efeitos não menos pungentes. Considere o diálogo entre música e ruído na cena em que um recém-desembarcado Lord Kitchener canta para um repórter de TV o tema "London is the place to for me" [Fig.14]. "Londres, esse é o meu lugar/ Londres, essa cidade é adorável/[...]Creia, estou falando de mente aberta/Sou feliz de conhecer minha terra natal/Tenho viajado a outros países nesses anos, mas este é o lugar que eu quero conhecer, querida/ Londres, este é o meu lugar", ouvimos, enquanto, lentamente, um ruído de ventania se faz notar e sobrepõe-se ao canto, como a emprestar um halo sinistro ao otimismo entoado nos versos.

Há nos sucessivos desembarques uma ênfase no desejo, mas, como vimos, essas imagens ora são abaladas por sons inquietantes ou se entrechocam com cenas de confrontos em Birmingham. Numa passagem mais explícita dessa ordem de relações, vemos um homem negro de meia idade, olhando diretamente para a câmera, manifestar sua vontade de integração na vida social da Grã-Bretanha, plano

Dossiê Apropriações e ressignificações na arte e no pensamento - https://revistaecopos.eco.ufrj.br/ 
sucedido por um corte abrupto a mostrar em seguida um carro incendiado [Figs. 16 e 17]. Procedimento idêntico é usado quando um outro imigrante, dessa vez visitando um museu do maquinário britânico, exalta a "atmosfera madura de eras de civilização" da Inglaterra e o corte, de súbito, nos leva outra vez a um quadro tomado por chamas [Figs. 18 e 19]. Esse vaivém entre o passado e o presente aparece no filme via uma montagem de colisões entre aspiração e desencanto, nas quais as expectativas da geração Windrush se vêem consumidas em signos saturados de violência. Conforme percebemos, as imagens de arquivo reempregadas em As Canções de Handsworth são como fantasmas a flanar pela paisagem de escombros em Birmingham. Neste filme, elas aparecem não tanto ao modo de uma "explicação", mas para absorver poeticamente o fracasso do sonho de emigrar, como se ressoassem a "esperança obscurecida de um mundo que tende a murchar por dentro e por fora de um eu exilado" (1983, p. 119, tradução nossa) evocada certa vez por Wilson Harris, também ele um antilhano radicado na Inglaterra no anos subsequentes à guerra.

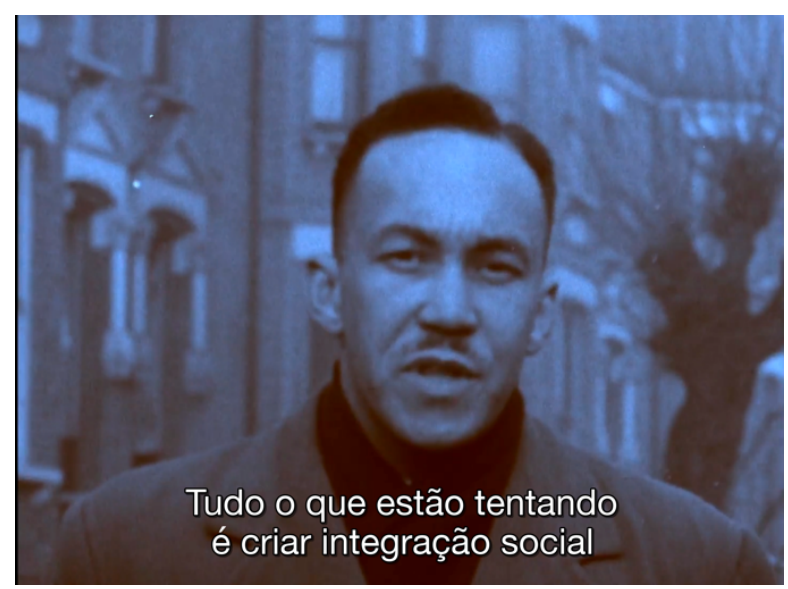

Dossiê Apropriações e ressignificações na arte e no pensamento - https://revistaecopos.eco.ufrj.br/ ISSN 2175-8689 - v. 24, n. 3, 2021 


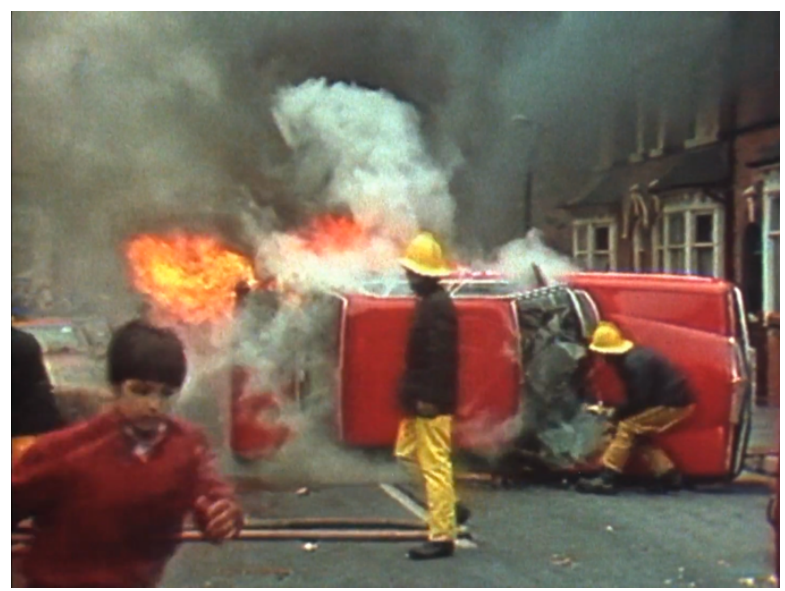

Figuras 16 e 17

As Canções de Handsworth
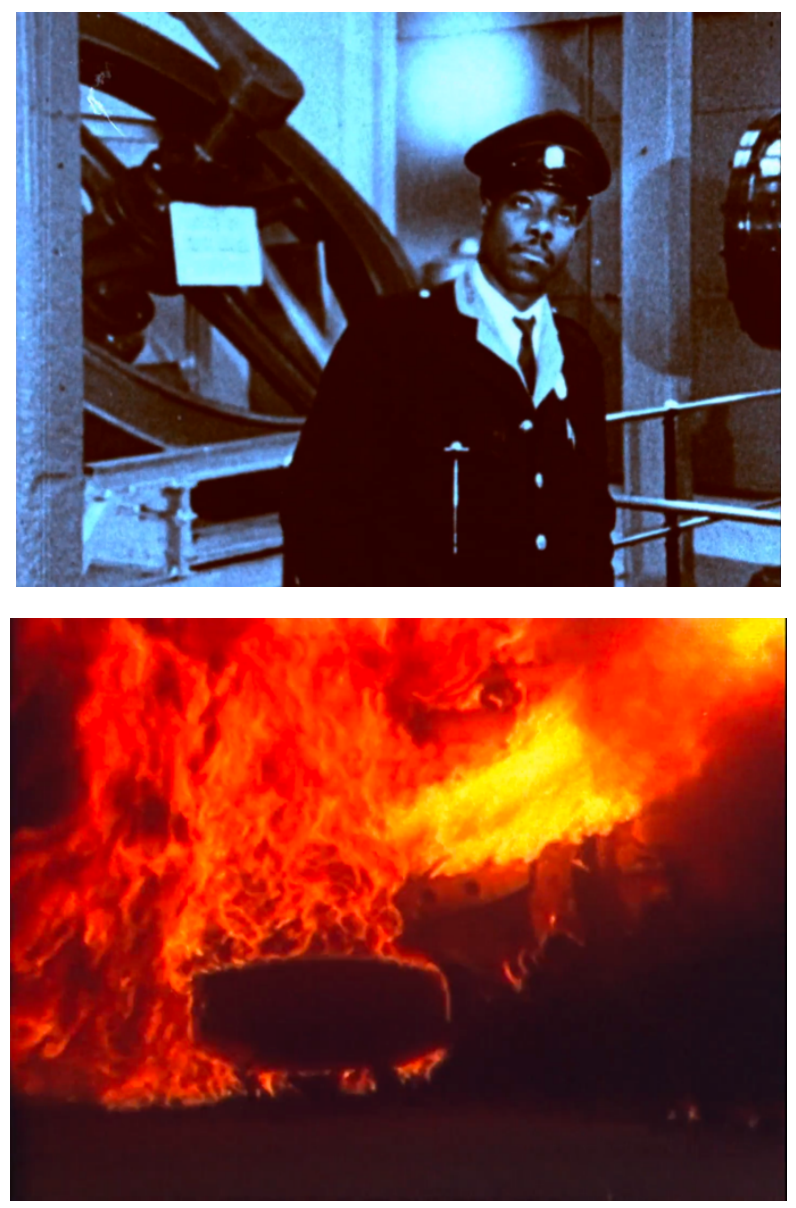

Figuras 18 e 19

As Canções de Handsworth

Dossiê Apropriações e ressignificações na arte e no pensamento - https://revistaecopos.eco.ufrj.br/

ISSN 2175-8689 - v. 24, n. 3, 2021

DOI: 10.29146/ecopos.v24i3.27766 
Interrogar o papel do arquivo em As Canções de Handsworth requer lembrar que as revoltas de Birmingham, assim como outras a elas associadas, como as ocorridas em Brixton em 1981, não foram as primeiras levadas a cabo pelas comunidades negras na Inglaterra. Confrontos com a polícia, barricadas e saques em bairros de imigrantes oriundos dos territórios coloniais aconteceram também em $1919,1948,1958$. Tais conflitos se originaram por força de ataques de grupos racistas a casas e estabelecimentos comerciais de famílias negras. A natureza dos levantes de Brixton e Birmingham, contudo, seria diferente. Na década de 1980, a centelha dos confrontos partirá das próprias comunidades de imigrantes, impelidas a contestar a situação de precariedade econômica, o terror policial e o racismo sistêmico na Grã-Bretanha7 . Havia à época um sentimento de desencanto geral a estimular uma outra experiência da diáspora no interior da nação. Diferentemente do anseio por integrar-se testemunhado nas imagens de arquivo reempregadas por Akomfrah, ensaiava-se então nos círculos diaspóricos formas de organização coletiva dissidentes, muitas vezes ansiosas por uma secessão a ser operada no coração da britanidade. Neste cenário, a ideia de uma filiação diaspórica traduzia não só "movimento e transnacionalidade" (Clifford, 1997, p. 252, tradução nossa), mas o ímpeto de instituir uma forma outra de situar, nomear, habitar a nação.

As Canções de Handsworth está decerto sintonizado com o campo de inquietações do seu tempo. Em seu primeiro filme, Akomfrah mobiliza, como observa James Clifford noutro contexto, “formas diferentes de ser 'britânico'” (1997, p. 252, tradução nossa). A montagem exasperada, permeada de cortes agressivos, empenhada em pôr em questão símbolos nacionais (o hino "Jerusalém”, a paisagem industrial, a própria figura de Margaret Thatcher [Fig.20]), bem como em tornar patentes as aspirações fracassadas da geração Windrush, manifesta uma obra sensível aos reflexos nervosos das ruas, embebida de um desejo de cisão com o paradigma dominante da britanidade.

\footnotetext{
7 Ver Olusoga (2016, p. 502-519).
} 
Tal impulso se exprime com força ao final do filme, quando vemos, numa imagem de arquivo, duas mulheres de origem indiana serem acompanhadas por um cinegrafista que as observa demoradamente, seguindo seus passos ao largo das ruas. Arredias, elas caminham apressadas. Carregando bebês a tiracolo, esquivam-se impacientes, ocultam a face nos sáris, até o momento em que uma delas se volta à câmera e agride-a com a bolsa [Fig.21]. A ideia defendida por Comolli de que "o sujeito sabe que ser filmado significa se expor ao outro" $(2008$, p. 80$)$ encontra nesta imagem sua máxima intensidade. Se a figura da câmera em ação é reiterada a todo instante em As Canções de Handsworth, aqui ela é golpeada de volta, atacada, sofre a resposta violenta da recusa em estar no quadro. Aquela negativa em participar do jogo engendrado pela câmera, a recusa na devolução do olhar daquelas imigrantes, insinua um germe de intransigência já no passado da geração Windrush. Com efeito, naquela relação violenta estabelecida no pós-guerra entre a mulher e a objetiva, Akomfrah encontra uma potente sinédoque do dissenso aspirado pelas comunidades negras a partir dos levantes raciais dos 1980.

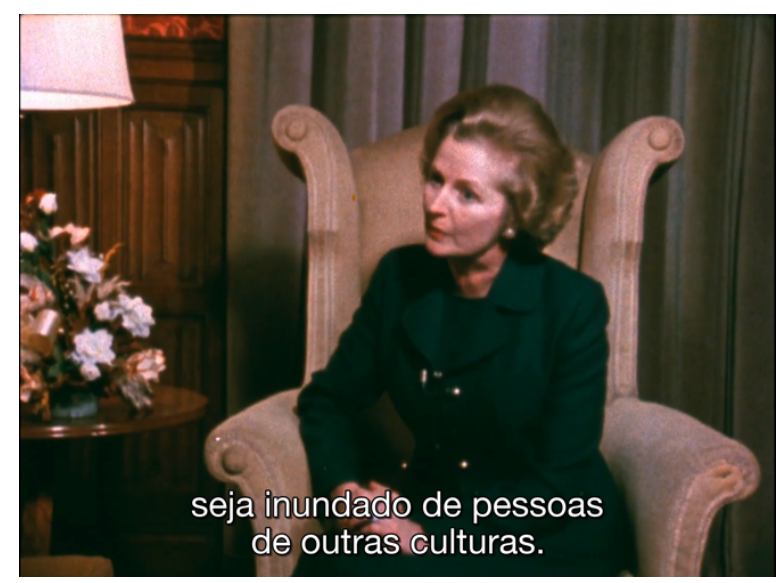

Figura 20

As Canções de Handsworth 


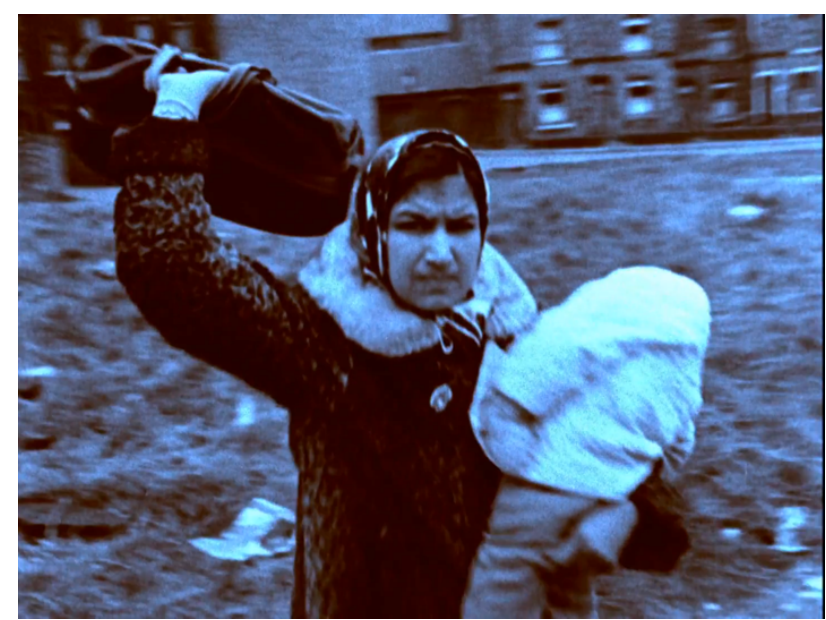

Figura 21

As Canções de Handsworth

Apesar de prevalecer em As Canções de Handsworth um discurso de nãoconciliação, a vontade de ruptura é infundida por um rasgo de melancolia. Como sabemos, o filme se insere na conjuntura das transformações neoliberais, quando a fé "na mente aberta" dos "homens nobres e maravilhosos de Birmingham", externada por aquele caribenho em visita ao museu fabril em 1960 [Fig.18] é solapada tanto pelo "medo de que este país [a Inglaterra] seja inundado por pessoas de outras culturas" quanto pela naturalidade com que "as pessoas irão reagir e ser hostis com aqueles que estão chegando", expressos por Margaret Thatcher, em entrevista também reempregada por Akomfrah [Fig.20]. Ao voltar-se à geração Windrush, o documentário acentua uma promessa falida de integração. Se, conforme mostra-nos a montagem, o desejo por assimilação foi estilhaçado, Akomfrah não observa o fracasso com desprezo ou ironia, enunciando antes um lamento pungente pelas esperanças frustradas daqueles homens e mulheres negros emigrados à Inglaterra do pós-guerra. Tal relação com a memória se traduz visualmente no desfecho da obra. As Canções de Handsworth se encerra com um plano aberto no qual uma mulher caminha solitária, passando ao largo de uma rua toda ela ladeada por um muro [Fig.22], paisagem onde não é possível se entrever 
qualquer horizonte, espécie de contracampo afetivo das cenas de desembarque tantas vezes reiteradas ao longo do filme.

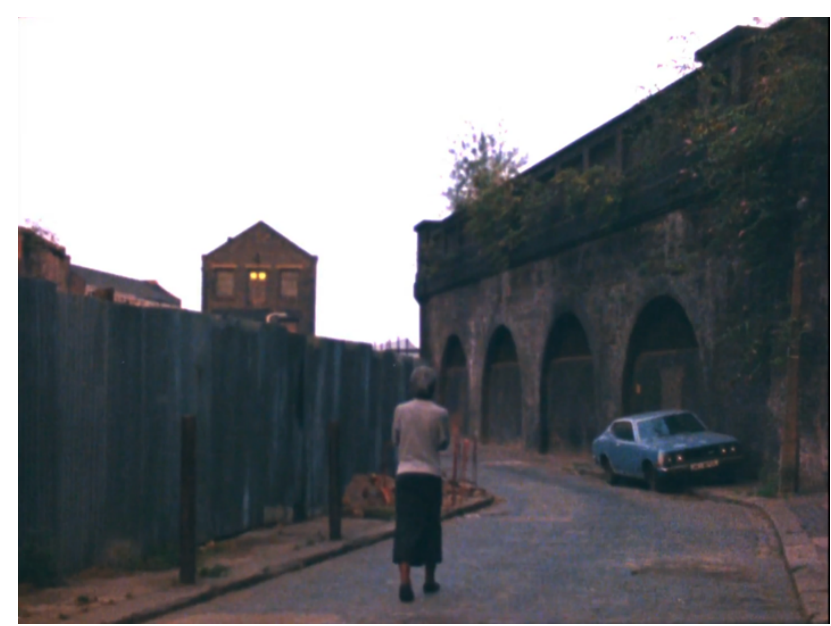

Figura 22

As Canções de Handsworth

\section{Referências bibliográficas}

AKOMFRAH, J. "John Akomfrah by Shezad Dawood". Entrevista concedida a Shezad Dawood. Bomb Magazine, Nova York, 19 jun. 2018a. Disponível em: <https://bombmagazine.org/articles/john-akomfrah/>. Acesso em: 06/09 2021.

AKOMFRAH, J. John Akomfrah. Entrevista concedida a Saha Birukova. Artecapital, Lisboa, 6 nov. 2018b. Disponível em: <https://www.artecapital.net/entrevista269-john-akomfrah>. Acesso em: 06/09 2021.

AKOMFRAH, J. John Akomfrah. In: CAREY-THOMAS, L. Migrations: Journeys into British Art. Londres: Tate Britain, 2012.

AMIEL, V. Estética da montagem. Lisboa: Texto \& Grafia, 2007.

Bailey, D; Hall, S. (2003), 'The Vertigo of Displacement', in L. Wells (ed.), The Photography Reader, London: Routledge.

BARTHES, R. A câmara clara: nota sobre a fotografia. Rio de Janeiro: Nova Fronteira, 1984.

Dossiê Apropriações e ressignificações na arte e no pensamento - https://revistaecopos.eco.ufrj.br/ 
BARTHES, R. O óbvio e o obtuso: ensaios críticos. v. 3. Rio de Janeiro: Nova Fronteira, 1990.

BENSE, M. On the Essay and its Prose. In: ALTER, N; CORRIGAN, T. (Orgs.) Essays on the Essay Film. New York: Columbia University Press, 2017.

CLIFFORD, J. Routes: Travel and translation in the late twentieth century. Cambridge: Harvard University Press, 1997.

COMOLLI, J. Ver e poder: a inocência perdida: cinema, televisão, ficção, documentário. Belo Horizonte: UFMG, 2008.

COMOLLI, J. Documento y espectáculo. In: CAPDEVILA, Ester (org.). Ideas Recibidas. Barcelona: Macba, 2012.

EISENSTEIN, S. A forma do filme. Rio de Janeiro: Zahar, 1990.

ESHUN, K. Drawing the forms of Things Unknown. In: ESHUN, K; SAGAR, A. The Ghosts of Songs: The Film Art of the Black Audio Film Collective. Liverpool: Liverpool University Press, 2007

HALL, S. A identidade cultural na pós-modernidade. Rio de Janeiro: DP\&A, 2006.

HALL, S. The young Englanders. London: National Committee for Commonwealth Immigrants, 1967.

HARRIS, W. The womb of space: the cross-cultural imagination. Westport: Greenwood Press, 1983.

LUKACS, G. Sobre a essência e a forma do ensaio: carta a Leo Popper. Revista Serrote, Rio de Janeiro: IMS, n. 18, p. 42, 2014.

MARKS, L. The skin of the film. Durham: Duke University Press, 2000.

NAFICY, H. The making of exile cultures: Iranian television in Los Angeles. Minneapolis: University of Minnesota Press, 1993.

OLUSOGA, D. Black and British: A forgotten history. Londres: Pan Macmillan, 2016.

RANCIÈRE, J. Figures of History. Cambridge, UK; Malden, Mass: Polity, 2014.

RANCIÈRE, J. The intervals of cinema. Nova York: Verso, 2019.

RUSSELL, C. Archiveology: Walter Benjamin and Archival Film Practices. Durham: Duke University Press, 2018. 